\title{
THE IMPACT OF THE MIGRATION CRISIS ON THE PROCESS OF SHAPING GOALS AND INSTRUMENTS OF THE EU IMMIGRATION POLICY.
}

\author{
Dr. Monika Trojanowska-Strzęboszewska \\ Institute of Political Science \\ Cardinal Stefan Wyszyński University in Warsaw \\ m.strzeboszewska@uksw.edu.pl
}

DOI:10.24193/OJMNE.2018.26.11

\begin{abstract}
:
The aim of the article is the reconstruction of the nature of the EU immigration policy that emerges from the EU's activities in the migration crisis, undertaken from 2015 till 2017. The analysis is focused on the legislative and political measures adopted by the EU according to the European Agenda on Migration, which was presented in May 2015. The implementation of this political agenda was de facto the EU's response to the unprecedented inflow of asylum seekers and economic migrants to Europe. The article underlines that security is a factor which fundamentally determines the EU's immigration policy from its very beginning, but after 2015 the security-oriented aspects of the EU's immigration policy was furthered strengthened. The EU's intervention in the migration crisis, giving priority to security-driven concern, was focused on meeting a 'secure borders' demand, understood as increasing the level of their closing (as opposed to opening) and impenetrability. As a result, the EU's response to the migration crisis has been very narrow, fragmented and insufficient in the shortterm, as well as in the long-term activities.
\end{abstract}

Keywords: European Union, border, security, immigration, asylum

\section{Introduction}

In recent years, immigration issues have dominated political debates and media reports in all European Union member states. Both in countries with significant shares of immigrants in their population and a relatively long and extensive history of migration policy and in countries with negligible numbers of immigrants and a poorly developed migration policy, the issues related to the rules and consequences of admitting immigrants and providing them with international protection have been added to the agendas of major state 
institutions and have become an object of heated disputes between parties. This has been accompanied by incredibly deep interest in issues of migration and refuge seeking manifested by mass media, which - especially in 2015 - every day bombarded public opinion with reports, comments and opinions concerning the unprecedented scale of immigration to the EU.

This incredible "revival" of the migration topic in European politics soon adopted a formula of disputes and conflicts between member states, as well as between political parties and groups in particular countries or in the European Parliament, referring to different outlooks on the world and ideological options. On the one hand, European societies faced the tragedy of hundreds of thousands of immigrants escaping war and persecutions in Syria and other Middle East countries, but also Africans seeking in Europe refuge from famine and drought, anarchy and ethnic wars, or simply looking for a better way of life and earning prospects. The scale of this exodus, the images of immigrants often crossing Balkan states on foot, and finally the scale of the tragedy of hundreds of people drowning in the Mediterranean Sea triggered various, sometimes extremely opposite, social reactions. On the other hand, at the level of institutions, domestic and European decision-making bodies, heated debates and disputes were waged over the answer the unified Europe should give to these phenomena. For the EU institutions, this was undoubtedly the period of an important test of the values and ideals worshipped by the European Union and a test of whether the EU has enough power and authority to pass and implement its answer.

In 2015-2017, a series of political and diplomatic initiatives were formulated, as well as institutional and legal solutions and financial proposals which were to build this common European reply (Carrera, Blockmans, Gros and Guild 2015). Seeking consensus, formal and informal meetings were convened in regional and Union circles, European leaders met in summits, had meetings with leaders of neighbouring countries; numerous debates were held in the forum of the Council, the European Council and the European Parliament. Despite all these actions, it was usually the lack of any agreement that prevailed over agreements (Czachór 2016). The parties to the dispute which crystallized in the course of the debates waged presented different ways of perceiving and assessing the migration events themselves, 
as experienced by the European Union at that time, and, consequently, different proposals on solving the matters considered "problematic" »§§§.

In the atmosphere of strong tensions and controversies, the EU, forced by the situation of mass immigration and the expectations of the public opinion of all member states, adopted its position in May 2015 in the form of the European Agenda on Migration (EC 2015). This document, a political signpost of the EU's activities in the migration area, defined the EU priorities in this field, both concerning activities requiring ad hoc reaction and long-term plans. In another two years, the agenda was specified by means of various executive orders and developed in the shape of legislative proposals introducing modifications to the broadly understood European Union policy on migration.

This article aims to present the nature of the European Union's immigration policy emerging from the reply given by the EU to the migration crisis (which was, more precisely, a humanitarian and a political crisis). Of vital importance for the analyses below will be the indication of the fundamental paradigm in which the adopted solutions are rooted, as well as the way of perceiving reality in the area of migration, emerging from this EU reaction to the migration crisis. The analyses presented will comprise an attempt at synthetic reconstruction of this paradigm, which, by assumption, constitutes some kind of generalization. It is important to demonstrate which interpretation of the migration events present in the European dispute laid the foundations for the solutions adopted. What values are inscribed in this European reply? What ways of solving problems stem from them? The object of the analyses will not be detailed characteristics and interpretations of particular elements in the EU migration agenda and resulting modifications of EU legislation, but the presentation of the main vectors, proposed solutions and consequences brought by giving particular meanings to its elements for creating the shape of the European Union policy on migration.

The first part of the paper presents a short description of the theoretical framework in which the analyses below are rooted, by underlining the concept of securitization. Then, the article discusses a typical feature of the EU immigration policy, namely positioning it within

$\S \S \S \S$ The analysis of the dispute over the migration crisis distinguished four main parties to the dispute, which forced different positions and arguments during the debates taking place in the European Council (or other EU forums): 1 / first-line countries (e.g. Italy and Greece) 2/ countries with a respectively high number of people applying for asylum and economic migrants (such as Germany, France, Sweden) 3/ Central and Eastern European countries (e.g. Hungary, Czech Republic, Poland) 4/ EU institutions like the European Commission and the European Parliament (Trojanowska-Strzęboszewska 2016). 
the discourse on internal security in the European Union. This context accounts for focusing the EU activities towards migration on issues related directly and indirectly to ensuring security, which leads to prioritizing some matters at the expense of others, but it also accounts for the fact that all issues related to migration in the EU are perceived in categories of threats and risks. An exemplification of this presentation is the postulate of safe borders, which, from the position of an appeal in the discourse on the migration crisis, conducted by leaders of member states and representatives of EU institutions, shifted into the position of a key "solution", comprising various EU activities taken as a reaction in the inflow of thousands of immigrants to the EU in 2015-2017. The implementation of this postulate will be characterized in the third part of the article, leading to conclusions regarding the narrowed, fragmented and insufficient EU response to the migration problem.

\section{What is securitization?}

The theoretical framework in which all the analyses below are rooted is made of constructivist statements and post-structural discourse analyses, currently widely used in research on European integration (e.g. Diez 2001; Christiansen Jørgensen and Wiener 2001; Delanty 1995; Risse 2009). These approaches divert from the belief that Europe has a stable identity, claiming that it is rather a certain idea, continuously constructed and reconstructed, “involved in disputes over politics and identity" (Walter 2005:17). Social constructivism stands on the position that social reality is constructed and reproduced through daily practice by human agents, but, on the other hand, the agents do not exist independently from the social reality (e.g. structures, ideas, norms, values) and its collectively shared system of meanings. That is why, when describing the European reality (e.g. European identity), it is crucial to assume that the Europeanization process has its effects on social identities of Europeans, so 'Europe' is also constituted by “a political and social space in people's beliefs and collective understanding” (Riess 2009:159). According to these approaches, political debates held in the EU forum around the issue of migration, and the language used to describe the migration phenomenon are not something that reflects reality, but which, perforce, constructs it, thus becoming a constitutive dimension of this reality. The definition of migration and an immigrant "forced" by EU decision-makers, the features, attributes and 
even intentions ascribed to them, they obviously influence political strategies adopted in the area of migration policy.

Another useful approach to the analysis below, starting from the theoretical assumptions of critical security studies (Bilgin 2012), developed within the constructivist approach to security (Buzan Wæver and Wilde 1998; Williams 2003), widely used in the area of international relations and political science, is that security and related issues also become social constructs, “a determined way of presenting reality” (Wæver 1996:106). This fundamental assumption of securitization theory means that it is impossible to ever fully assess whether security and security threats are 'real' or not. In its broadest sense, "the concepts of securitization implies that threats are not out there but constructed by social actors” (van Munster 2009:5). According to Ole Wæver and his colleagues from the so-called 'Copenhagen School', a security issue arises as a result of the discursive process that makes it very important and requiring immediate response. The creators of the securitization theory pointed out: "'Security' is thus a self-referential practice, because it is in this practice that the issue becomes a security issue - not necessarily because a real existential threat exists but because the issue is presented as such a threat” (Buzan, Wæver and Wilde 1998:24). Therefore, the securitization of the issue by a securitizing actor within a 'speech act' defines the issue - as part of the discourse - as an existential threat to the survival of a 'referent object' (such as a nation, a society, a state) and needs the acceptance as such by the 'audience' of the speech act (e.g. public opinion). In this approach, the EU policy towards immigration is not only an attempted reply to real and objective problems related to the growth of international crime, especially terrorism or the growing unwillingness of European societies to accept immigrants (which is difficult to deny), but also as a result of effective rhetorical "education" in which particular issues are interpreted as threats and risks to security.

What is also important it is that the securitized issue requires "emergency measures and actions outside the normal bounds of political procedure” (Buzan, Wæver and Wilde 1998:25). As Ole Wæver noticed, the securitizing actor "moves a particular development into a specific area, and thereby claims a special right to use whatever means are necessary to block it” (1995:55). 
The original version of the securitization theory was further developed and redefined. Some scholars have retained the emphasis on the role of speech acts in the securitization processes and apply securitization as an approach to the study of public discourses (e.g. analysing political speeches). Others, led by Didier Bigo, have left the study of securitization through speech acts and shifted to the study of securitization through practice. Bigo assumed that some issues can be securitized "without speech or discourse and the military and the police have known that for a long time. The practical work, discipline and expertise are as important as all forms of discourse” (2000:194). Highlighting the role of practice, Bigo referred securitization processes mostly to practices of bureaucratic experts, acting in the frame of structures and networks linked to security practice and using specific technologies.

Advocates of this approach, like Sarah Leonard, add that "it is also more adequate to focus on practice, rather than discourses, when analyzing securitization processes (regarding not only migration and asylum, but also other issues) in the EU... The EU is evidently not the state; it has no government or president to make the kind of dramatic securitizing speech acts that can be identified in national contexts” (2011:236). On the other hand, the EU is not solely a bureaucratic body; it is at least equally a political community, plunging into emotions and tensions between member states (or between member states and European institutions). As Rens van Munster rightly notes, "the political and bureaucratic levels of the EU are mutually constitutive (..), and although the main security dynamics are located at the bureaucratic level (...), the political level often plays an important role in either authorizing, legitimizing, justifying, thwarting, dislocating or upsetting the enunciations of security professionals” (2009:6).

\section{The EU migration policy in the frame of security}

The main thesis of this paper is the acknowledgement that the EU immigration policy is shaped within the discourse on European security, which provides political narrations on migration with main explanation and interpretation schemes. The debate over the refugee humanitarian crisis or, more broadly, the migration crisis and the EU activities from 20152017 that followed it, not only emphasized these issues, but also gave the security dimension absolute priority in the EU agenda on migration. 
The above can somehow be attributed to the fact that from its very origins, the development of the EU immigration policy was a consequence of freedom to cross borders within the Schengen zone. This policy was initiated as one of a whole range of compensation means, i.e. solutions aimed at improving security due to its potential weakening stemming from eliminating controls on borders between member states. This led to focusing the EU activities in the area of immigration on solutions concerning rules for foreigners' entry and stay in the Schengen area, which created various constraints and barriers from the very beginning.

Since 1999, when the Schengen area became part of the EU due to the entry into force of the Amsterdam Treaty, one of the key objectives of the Union has been to provide its citizens with an area for freedom, security and justice (European Union 2012: article 3). The process of accomplishing these goals has become a dynamic and important sphere of EU activities and, simultaneously, a daunting task, since it is related to strongly "nationalized" issues, such as security, citizenship or political identity. The treaty provisions offer a specific understanding of what this space of freedom, security and justice is. It has been assumed that it means that within it there are no internal borders and there is "the free movement of persons ... in conjunction with directly related flanking measures with respect to external border controls, asylum and immigration, and preventing and combating of crime” (European Union 2012: article 61 point a). In other words, in order to ensure that EU citizens enjoy freedom understood as freedom of movement, some activities are undertaken, aimed at ensuring security and related to: controls of external borders, asylum, immigration, preventing and combating crime. Therefore, the issues concerning rules of crossing borders, asylum and immigration are, first of all, institutionalized in the same area as the issues of international crime (for example trans-border crime or terrorism), and secondly, they are placed in the space of potential threats to the internal security of the EU (Bigo 2002).

Moreover, in the Vienna Action Plan (the programme for the implementation of the provisions of the Amsterdam Treaty referring to the AFSJ), "the freedom to live in a lawabiding environment is in turn operationalized as the freedom from those who are identified as abusers of that freedom" (van Munster 2009: 74). Analysing the process of institutionalization and operationalization in the area of freedom, security and justice within the EU, as well as the disputes led in the European Council and during the intergovernmental 
conferences over the issue, Munster points out that "freedom and justice are overdetermined by the meaning of security [and], freedom is discussed mainly in negative terms, as threats to freedom that should be neutralized” (2009:142).

Such an understanding of the triangle of objectives (and also values), rooted in the Treaty of the European Union, and its former revisions, and the political agendas referring to JHA (such as Tampere Agenda, Hague Programme, Stockholm Programme) has been maintained and even strengthened (as a reaction to some terrorist attacks in a few member states) for years on the basis of EU political and legal documents. Didier Bigo, examining the Hague Programme, concluded that we should change the title of that part of EU activities and "adapt the title to their actual content by renaming the three parts: 1. strengthening security, 2. strengthening security, 3. strengthening security" (2006:35). That explains why in the EU's discussions about migration, the emphasis is usually shifted from debates on immigration, including integration of immigrants, onto debates on security (Roos 2013).

As an effect of this, the EU migration policy was created and shaped in the security frame. Over the next - almost two - decades, focusing on security issues in immigration policy has led to the largest development of those policy aspects directly and indirectly related to general rules and conditions of entry and residence of foreigners in the EU. There were adopted and implemented regulations referring to selected specific areas in the scope of EU law, such as visas, border protection and control, fighting illegal immigration, returns and readmission, and fighting trans-border crime. The legal dynamics of the EU security-oriented migration policy was supplemented by a gradual development of an operational and institutional dimension. The EU created the second-generation Schengen Information System, Eurodac (a large-scale fingerprint database), Visa Information System, European Border Surveillance System (Eurosur), and Frontex (European Agency for the Management of Operational Cooperation at the External Borders of the Member States of the EU), all of which are focused on the management of the external borders of the EU.

Border management became a core element of the EU immigration policy, developing under the narratives of the growing threat to internal security and public order, not solely from terrorist organizations and organized crime, but also form the massive flow of migrants and asylum seekers. In practice, this policy strengthens the syndrome of "Fortress Europe" (Gruszczak 2012) and is dominated by instruments preventing irregular entry to the EU and 
expelling irregular migrants from the EU. As Andrew Geddes claims, the concentration on restrictive and exclusive migration policy and instruments referring to the EU borders justified the fact that the issue of immigrants" inclusion was "pushed aside" (2000). Moreover, immigrants are often left outside the networks of integration, socialization and needed protection, which can push them towards networks of alienation and radicalization, and even violence and crime.

\section{The postulate of "secure borders" as a reaction to the migration crisis}

It must be noticed that the way of presenting threats to security in the EU policy referring to immigration and asylum affects the interpretation of the concept of safe border. This is combined with the general process within which traditional recognition of secure borders as a manifestation of independence and sovereignty, associated most of all with military issues, has been extended to comprise a whole range of non-military threats. These processes are connected with the changes in reflections on security which took place after the end of the Cold War, indicating the growing role of such dimensions as political, economic, social and ecological (Buzan 1991). In this interpretation, the movement of people and goods through the borders may also constitute a challenge to security. Therefore, we may look at the development of policies directed at institutionalizing the movement of people and the flow of goods through borders, which has been progressing since the $1^{\text {st }}$ World War, both in Europe and in other parts of the globe, as at creation of instruments for internal security defence in terms of domestic goods production markets, labour markets, social security systems, healthcare systems and, finally, cultural and social integrity as elements of cultural security.

As a result of these processes, borders become an instrument of many policies directly and indirectly related to the area of security. Secure borders are not only borders which can effectively protect us against invaders, an enemy army in the military sense; they are also borders which eliminate smuggling and other types of trans-border crime, but above all, their role in managing migration has developed. And since migrations in the European discourse and the EU policy "have become” the space bringing risk and threat, a natural instrument for managing them is found in borders, as obstacles and barriers protecting us from the undesirable and dangerous. Especially after the terrorist attacks in the USA in 2001, the 
postulate of 'secure border' had become a key task to be accomplished by governments individually, and by the EU as a whole.

The climax of such appeals was observed in 2015, when - as Frontex submitted along the external borders of the EU over 1.8 million instances of unauthorized border crossings were reported (2016:6), over one million more cases than in the previous six years combined (2009-2014). More importantly, the migration pressure accumulated along two migration routes: East-European (and its Balkan continuation) and Central European. This meant that the problem of unprecedented scale of immigration to the EU at that time was worsened by the uneven concentration of the immigrant and refugee flow in a few geographic bottlenecks.

This created a situation where some EU countries were particularly burdened with this problem and determined the forced ways of solving them. Representatives of European institutions and leaders of countries and governments in the centre of the EU demanded that the border countries, especially Italy and Greece, restored order on the borders and managed the chaos of mass and uncontrolled movements, including secondary movements (those between member states). In the EU institutional forum, these countries were blamed for insufficiently protecting the European external borders, which resulted in the growing uncontrolled immigration into the EU. The EU countries which were immigration destinations (for example Germany, France, United Kingdom) and the countries with a high rate of submitted asylum applications (Germany, Sweden, Austria) expected that the EU efforts should be concentrated on the immediate tightening of its external southern borders and reinstating the systematic registration of newcomers and abandoning activities resulting in secondary flows (inside the EU). For the failure to observe EU law in this scope - the activities of Greek authorities trying to cope with the mass inflow of migrants through the leaking border, which allowed to avoid registration of some of them and thus not to incur the costs of their reception - Greece was even threatened with removal from the Schengen zone (Taylor 2016). The Dutch prime-minister warned that as history teaches us, "even great empires fall when their borders are not well guarded” and argued that tightening the GreekTurkish border was an absolute priority of the EU facing the refugee crisis (Bielecki 2015). Thus, the Netherlands, which took the lead in the Council, set as its goal the development and quick implementation of the common EU position on securing the EU external borders, 
Issue no. 26/2018

which translated into, inter alia, supporting the initiative of the European Commission from December 2015 on, and establishing a European Border Guard Agency (BorońskaHryniewiecka 2016).

What is obvious is that also the first-line countries, those responsible for controlling external borders, directed their expectations towards joint EU activities at the improvement of border controls. In their appeals for security, Italians and Greeks demanded mostly financial support from the EU for staff and infrastructure improvements to protect their own borders (for example, providing them with state-of-the-art equipment for controlling and supervising). They also required the EU to join very costly search and rescue actions in the Mediterranean Sea, organized by the Italian navy (Brady 2014). Exceptionally, Italy’s appeals concerning the involvement of the EU foreign and security policy in operations on the Mediterranean Sea were supported by the High Representative of the EU for Foreign Affairs and Security, Federica Mogherini. Moved by the tragedies occurring at sea, she declared at the beginning of 2015 that she intended to add migration matters to the agenda of the Council for Foreign Affairs and added that "the fight with smuggling and illegal border crossing, saving migrants at sea and protecting people seeking asylum are our common challenges” (Blockman, Russack 2015).

Whereas most countries of the so-called old EU more or less supported the proposals for revision of the asylum system in the EU, prepared at that time by the European Commission, which was to be an integral part of the EU answer to the migration crisis in 2015, new member states, most notably the Visegrad Group countries, concentrated on adopting solutions aimed at tightening borders. This tone can be found in their joint statement from September 2015, in which they demanded putting aside the plans for refugee relocation and, instead, intensifying activities for strengthening controls on borders and improving the system of sending immigrants back (Joint Communiqué 2015). In many statements, they emphasized that we need to look at the issue of the migration crisis through the prism of the 
effective operation of the Schengen zone, particularly security on its borders, not from the perspective of developing common immigration and asylum policy ${ }^{* * * * *}$.

Therefore, in the particular crisis situation of 2015, where the scale of migration problems turned out to be unprecedented and where related conflicts between member states aggregated, security issues undoubtedly constituted a common denominator. In this perspective, borders became somehow a natural key instrument of the EU immigration policy and EU efforts were directed at protecting these borders against the unwanted inflow of immigrants. A postulate which in the space of sharp EU disputes and tensions concerning changes to the common asylum system and establishment of the relocation mechanism and organization of resettlement of immigrants from refugee camps gained unanimous approval of all parties to the discussion was the postulate concerning ensuring security on borders. Although for some (countries admitting the biggest numbers of refugees, international institutions), it was a postulate which should be accompanied by the simultaneous revision of the asylum system so that the countries could jointly be burdened with the costs of the inflow of thousands of people seeking asylum in the EU, other countries (Visegrad Group states) treated this postulate as the essence of EU solutions, which could be at most accompanied with intensified actions supporting (materially and financially) refugees in their countries of origin or their staying in camps located in third countries (Trojanowska-Strzęboszewska 2016).

The postulate of 'safe borders' has thus become a significant space of consensus, extremely needed by the EU during the aggravating political conflict over the migration crisis. But this postulate is only seemingly a specified reply, in fact being a capacious and plastic rhetorical figure, changing in time. Filling this postulate with some content is connected with the way in which we define security itself.

\footnotetext{
***** See Orban: Europe must protect its border, „Daily News Hungary” (24.04.2015), Available at: http://dailynewshungary.com/orban-europe-must-protect-its-borders/html. Also, the Polish vice minister of foreign affairs underlined in December 2015 that: "The Polish government does not understand why someone wants to combine two unlinked issues: the future of the Schengen area and immigration” (Denkova, Robert, Schwartz et al. 2016).
} 
Issue no. 26/2018

\section{The European Agenda on Migration and its implementation}

Taking into consideration the above postulates, we need to analyse the EU's reaction to the migration crisis, referring both to the common European agenda on migration, adopted in May 2015, and to what the EU actually managed to accomplish from the plan (European Commission 2016a). The European Commission, which proposed the European Agenda on Migration, included two groups of actions in it: ad hoc, to be implemented immediately, and long-term actions, related to the further development of the migration management policy. Among ad hoc actions, though admittedly they were rather slow and definitely delayed, the Commission indicated: 1/ increasing the abilities and means dedicated to joint supervision and rescue operations on sea borders conducted by Frontex, the so-called "Triton” (run by Italy) and "Poseidon” (Greece), 2/ the necessity to direct actions against smugglers' networks using the instruments of Common Security and Defence Policy, 3/ adopting the mechanism for the relocation of people applying for asylum to spread evenly the costs related to acceptance of waves of newcomers to the EU, 4/ implementation of the resettlement programme (20 thousand people) in order to create legal ways of reaching the EU for people seeking international protection, 5/ cooperation with third countries aimed at coping with migration in the areas of migrants' origin and transit, 6/ implementation of the so-called hot spot approach, that is establishing along Greek and Italian borders additional points of identification, registration and verification for people crossing external borders, $7 /$ providing additional financial means to satisfy the needs of the bordering member states (European Commission 2015).

On the other hand, in the long run, the European Union proposed concentrating on "four pillars of better migration management": 1/ limiting incentives for illegal immigrants, including fighting smugglers and human traffickers, and activating steps aimed at organizing returns of immigrants who irregularly stay on the EU territory 2/ managing borders - saving life and securing external borders (inter alia by strengthening the role and capabilities of Frontex, determining the EU norm concerning border management, strengthening coordination of domestic tasks of coast guards, putting forward once again the initiative of the so-called intelligent borders, supporting third countries in effective management of their own borders), 3/ a firm common asylum policy (including increasing the degree of coherence in implementing the asylum law in member states to fight abuses of the asylum system, 
strengthening provisions concerning a safe country of origin, intensifying actions aimed at biometric identification of people seeking asylum and possibly a review of the Dublin system), 4/ a new policy towards legal migration (for example, changes to the blue card, establishing a platform for dialogue with social partners on economic migration, more actions combining migration policy with development, changes to priorities in financing integration policy) (European Commission 2015).

The next months showed that the Commission's above proposals, though developed as petitioned by the European Council and as an answer to the resolution of the European Parliament, were only fragmentarily accomplished.

Among ad hoc actions, the issues concerning the implementation of the relocation systems and refugees' resettlements have been met with strong resistance or tardiness of some countries, which brought on the collapse of both initiatives in practice. Thus, the EU efforts have been concentrated on the issues consisting of tightening external borders. But even in this respect, it should be noted that the military operations started in June 2016 in the south-central part of the Mediterranean Sea (taken up within the CFSP) to counteract human smuggling and trafficking were relatively quickly stopped. As it was explained then, "the chance of being rescued [offered to immigrants by the presence of ships and other military equipment - own comment] encourages the choice of the risky sea route" (Kingsley 2017:15).

The focus of EU migration activities on security issues becomes even more visible when we look at the current implementation of the long-term actions proposed by the Commission. On the basis of the presented provisions, the Commission prepared a few legislation proposals, aimed mainly at strengthening and tightening EU external borders. The first one, of vital importance, was - accomplished in 2016 - the establishment of the European Border and Coast Guards and transforming the Frontex agency into the Border and Coast Guard Agency, by strengthening and widening the competences of the Agency directly and indirectly - in matters of controlling the external borders of the EU. Secondly, the European Commission proposed and the Council and European Parliament adopted a crucial change to the Schengen Border Code, particularly by introducing checks against the SIS II and Interpol databases on all persons (third country nationals, as well as persons who enjoy the right of free movement), both at entry to and at exit from the EU, fundamentally 
widening the scope of the border control. Finally, at the end of 2017, the European Commission presented a legal proposal establishing the Entry/Exit System as part of the intelligent borders initiative. The system gained the European Parliament's and Member States' acceptance and - in the next years - should be applied to third-country nationals admitted for a short stay into the Schengen area. The idea of the system is to record information of time and place of entry, and the length of stay of migrants in the Schengen area, and to generate automatic alerts directly to the competent authorities in case of 'overstaying'.

An important supplement to the dominant viewpoint of securitizing immigration issues were also actions taken by a number of European countries on their own. They also involved the implementation of the postulate of 'secure borders', but were tested on the domestic level, when the EU actions were considered insufficient and taking too long. The most important issue in this respect was the erection of additional fencings and barriers along the borders by some countries. As early as June 2015, Hungary was the first to start building barbed wire entanglements along their border with Serbia, an external border of the EU, and when refugees turned to Croatian lands, they extended the programme of building border fencings also to the border with Croatia and Romania, both EU countries which do not belong to the Schengen area. Hungary was followed by Slovenia, which erected fences on part of its border with Croatia. Along with erecting these structures, border services were equipped with paramilitary appliances, such as drones or light planes, and finally, army forces were asked, as they informed, to provide security on borders.

Another variant of implementing the postulate of 'secure borders' were the actions introduced by the countries which were the final destinations for immigrants and refugees. Of vital importance was to restore - in line with EU law and as long as it was the ultimate measure, used when facing threats to the Schengen area and for a definite period of time controls on internal borders, namely on German, Austrian, Slovenian, Swedish, Norwegian and Belgian borders (European Commission 2016b). In May 2016, five countries most affected by the problem of mass inflow of migrants (Austria, Germany, Denmark, Sweden and Norway) prolonged for 6 months the restored proportional, temporary border controls as a reaction to "serious threats and in order to keep public order and public security in connection with secondary flow of irregular migrants” (Rada 2017). France also decided to 
reintroduced border control on its land borders after the terrorist attack in 2015 in Paris. All these countries prolonged their border control a few times for the following months. Thus, these 'temporary' measures of reintroducing controls on internal borders have been used for more than two years. Thus, the European Commission proposed a new amendment to the Schengen Border Code, allowing countries to reintroduce border controls even up to 3 or 4 years.

To summarize, in reaction to the migration crisis, whose significant dimension was the refugee crisis, both at the EU and at the national level, the postulate of 'secure borders' was used. Border security generally boiled down to the care for the security of the receiving societies, practically omitting the issues of the persons who were crossing these borders. Secure borders were understood as tight borders, even impenetrable ones, those which prevent or at least limit significantly the inflow of threats and risks to European societies, as such threats and risks were perceived in unwanted immigrants. Tightening the borders thus gained two key interpretations. Firstly, it was implemented by means of intensifying controls on external borders by developing institutions, funds and specific instruments (including military ones) used for limiting the inflow of immigrants into the EU, or even through symbolically 'closing' the borders by erecting physical border defences, such as walls or barbed wire fencings. Secondly, tightening the borders also meant a 'restoration of borders', referring to the temporary reintroduction of personal controls on selected internal borders and establishing additional limits concerning, for example, the right to submit applications for international protection (like in Austria and Germany in 2015).

In all indicated actions, borders have become important elements protecting against mass and undocumented immigration, regardless of the fact that this group also included people seeking asylum. The functions of borders were narrowed down to creating a tight barrier protecting a particular society, community or political organism against the external forces that threaten its existence, survival, stable existence etc., and irregular immigration to the EU was considered to be such a major force.

\section{Conclusions}

The aim of the article was to present the nature of the European Union's immigration policy emerging from the actions taken by the $\mathrm{EU}$ as a response to the migration crisis 
connected with the unprecedented inflow of great numbers of economic immigrants and people seeking asylum in the member states in recent years. The article shows that security has become the factor regulating the EU immigration policy, determining how it is conducted (and developed), whereas the notion of security itself and the meaning ascribed to it have fundamentally affected the shape and nature of the adopted solutions within this policy. In the crisis connected with the inflow of a large number of migrants into the EU, including potential refugees, the exemplification of adopting the paradigm of security in the EU immigration policy has been the implementation of the postulate of 'secure borders', understood as achieving the highest possible degree of their tightness and impenetrability.

As a result, the EU's reaction to the immigration crisis has proved to be a fragmentary, reductionist and, in the long run, insufficient approach to migration issues. First of all, this means that the top priority in EU activities towards immigration are the issues connected with rules and regulations governing immigrants' entry and stay in the EU. This issue is already reduced and concerns mostly actions aimed at limiting the inflow of unregulated immigration into the EU, through developing legal, institutional and financial instruments within the integrated management of the EU external borders and the policy of returns, deportations and readmissions. It should be noted that the very definition of what is and what is not unregulated immigration has not only been rendered relative, but also political. As a result, the issues concerning legal migrations, including potential challenges revealed in this area for many years, have been pushed out of the European focus.

Secondly, this brings about some consequences - marginalizing the issues from other areas of immigration policy, especially issues concerning the immigrants' integration policy. These issues, though mostly vital for internal security and public order in member states (for example, due to processes of radicalization of attitudes and growing terrorist threats), have not become the subject of EU debates or the area for which effective strategies and instruments are created at community level.

Thirdly, subordinating the EU immigration policy to the security paradigm results in the securitization of asylum policy and, so to speak, the 'suspension' of the humanitarian dimension of this policy. Bearing in mind the fact that border control and asylum policies are in fact inseparable, focusing EU actions on implementing the restrictive admission policy leads to deficits in the EU's legal, international and moral commitments concerning its policy 
Issue no. 26/2018

towards refugees. These processes were also associated with - well visible in many EU and domestic debates - blurring distinctions between people seeking asylum and irregular economic immigrants, which in practice translated into political postulates to deny these people entry into EU territory. In public rhetoric, the category of 'refugee', just like an economic immigrant before, was gradually subjected to processes of securitization and the refugee, from a person seeking shelter and international protection, escaping war and anarchy that threaten their life, has become a person who carries this threat with them and who threatens public security and order in the EU member states.

And fourthly, reducing the EU actions concerning immigration to the fight against irregular immigration by means of strengthening border controls or establishing additional barriers to migration means, in fact, the implementation of a highly ineffective policy. This is mainly because it is based on vain expectations that borders will become effective barriers to population flow. The approach consisting of identifying secure borders with their tightness denies the facts and regularities described by scientists for many years. There is no easy way of blocking the migrants' routes, but they can be better organized ${ }^{\dagger+1+\dagger}$. What is more, it will be difficult to stop desperate people who, regardless of whether they are welcome in the EU or not, will come here since - to put it short - they are subjected to very strong pushing factors. Finally, this approach denies the fact that porosity is an inherent feature of borders (Brunet-Jailly 2007:2). This feature makes the provision of 'secure borders' a special challenge to security policies. It is necessary in this respect to recognize that "security is not equal to freedom and cannot be treated as a goal itself” (Jeandesboz 2016:17). Security is a measure adopted to provide greater freedom and protection of fundamental rights.

\footnotetext{
t+r+t The activities limiting the inflow of immigrants in one migration route lead to the growing inflow via other routes, which can be seen in the period of 2014-2016 in the changing routes that refugees from Syria took when fleeing to Europe: first, in 2014, Syrians escaped through Jordan to Egypt and mostly to Libya, where they embarked on boats sailing to Europe along the so-called mid-Mediterranean route. In 2015, the situation changed, as the war broke out in Libya and Egypt - pressed by the EU - introduced stricter visa requirements. The Syrians started to flee to Turkey and then, through the Aegean Sea to Greece and then along the Balkan route to Central Europe. This East-European route was blocked by the agreement between the EU and Turkey, concluded on $16^{\text {th }}$ March 2016. Refugees obviously did not disappear - merely one month later, the rates of Syrians trying to enter the EU via the Central European route increased significantly.
} 
Issue no. $26 / 2018$

\section{Bibliography}

- $\quad$--- “Orban: Europe must protect its border” (2015) In: Daily News Hungary. 24 April. Available at: http://dailynewshungary.com/orban-europe-must-protect-itsborders/html.

- BIELECKI, T. (2015) "Unia na łasce Erdogana" In: Gazeta Wyborcza. 27 November.

- $\quad$ BIGO, D. (2000) "When Two Become One: Internal and External Securitization in Europe” In: KELSTRUP, M. and M.C. WILLIAMS (eds.) International Relations Theory and the Politics of European Integration: Power, Security and Community. London: Routledge.

- BIGO, D. (2002) "Security and Immigration: Toward a Critique of the Governmentality of Unease” In: Alternatives. 27. pp. 63-92.

- BILGIN, P. (2012) “Teoria krytyczna” In: WILliAMS, P. D. (ed.) Studia bezpieczeństwa. Kraków: Wydawnictwo Uniwersytetu Jagiellońskiego.

- $\quad$ BLOCKMAN, S. and S. RUSSACK (2015) “The Commissioners’ Group on External Action - Key Political Facilitators” In: CEPS Special Report. 125.

- BOROŃSKA-HRYNIEWIECKA, K. (2016) „Holenderskie przewodnictwo w UE: między poszukiwaniem jedności a skutecznością polityczną” In: Biuletyn PISM. 3.

- $\quad$ BRADY, H. (2014) „Mare Europaeum? Tackling Mediterranean migration” In: Brief. European Union Institute for Security Studies. September.

- $\quad$ BRUnet-JAilly, E. (2007) Borderlands: Comparing Border security in North America and Europe. Ottawa: University Ottawa Press.

- $\quad$ BUZAN, B. (1991) People, States and Fear: The Agenda for International Security Studies in the Post-Cold War Era. $2^{\text {nd }}$ edition. Hemel Hempstead: Harvester Wheatsheaf.

- $\quad$ BUZAN, B.; WÆVER, O. and J. de WILDE (1998) Security: A New Framework for Analysis. London: Rienner.

- $\quad$ CARRERA, S.; BLOCKMANS, S.; GROS, D. and E. GUILD (2015) “The EU's response to the Refugee Crisis: Taking Stock and Setting Policy Priorities”. In: CEPS Essay. 20. Brussels, 14

November. Available at: 
https://www.ceps.eu/system/files/EU\%20Response\%20to\%20the\%202015\%20Refugee\%20 Crisis_0.pdf.

- $\quad$ CHRISTIANSEN, T.; JØRGENSEN, K. E. and A. WIENER (ed.) (2001). Social Construction of Europe. London: Sage.

- $\quad$ CZACHÓR, Z. (2016) "Wzrost antyimigracyjnego radykalizmu i eurosceptycyzmu jako wyzwanie dla przyszłości Unii Europejskiej” In: WOJTASZCZYK, K. A.; SZYMAŃSKA, J. (ed.) Uchodźcy $w$ Europie. Uwarunkowania, istota, nastepstwa. Warszawa: Oficyna Wydawnicza ASPRA-JR.

- DELANTY, G. (1995) Inventing Europe: Idea, Identity, Reality. Basingstoke: Palgrave Macmillan.

- $\quad$ DENKOVA, A.; ROBERT, A. and A. Schwartz et all (2016) Mini-Schengen not an option, for now. 25 $5^{\text {th }}$ January. Available at: http://www.euractiv.com/section/centraleurope/news/mini-schengen-not-an-option-for-now/.html.

- DIEZ, T. (2001) "Europe as a Discursive Battleground: the study of Discourse and the analysis of European Integration Policy”. In: Cooperation and Conflict. 36.

- $\quad$ EUROPEAN UNION (2012) “Consolidated Version of the Treaty on European Union and the Treaty on the Functioning of the European Union”. In: Official Journal. C 326 (26.10.2012).

- $\quad$ Frontex (2016) Risk Analysis for 2016. Warsaw.

- GEDDES, A. (2000) Immigration and European Integration: Towards Fortress Europe? Manchester: Manchester University Press.

- JEANDESBOZ, J. (2008) "Reinforcing the surveillance of the EU Borders. The Future Development of Frontex and Eurosur”. In: Challenge Liberty \& Security. Research Paper. 11.

- Joint Communiqué of the Visegrad Group Ministers of Foreign Affairs (2015) Prague. Available at: https://www.msz.gov.pl/pl/polityka_zagraniczna/europa/grupa_wyszehradzka/spotkanie_szef ow_dyplomacji_panstw_grupy_wyszehradzkiej_niemiec_i_luksemburga_w_pradze;jsession id=ADD28607D1DA4678579A78BEDD3ED78C.cmsap4p.html. 
- $\quad$ KINGSLEY, P. (2017) Nowa Odyseja. Opowieść o kryzysie uchodźczym w Europie, Warszawa: Wydawnictwo Krytyka Polityczna.

- $\quad$ KOMISJA EUROPEJSKA (2015) Komunikat Komisji do Parlamentu Europejskiego, Rady, Europejskiego Komitetu Ekonomicznego i Komitetu Regionów: Europejski program w zakresie migracji. COM (2015) 240 final. Bruksela (13.05.2015).

- $\quad$ KOMISJA EUROPEJSKA (2016a) Komunikat Komisji Europejskiej do Parlamentu Europejskiego $i$ Rady dotyczacy stanu realizacji działań priorytetowych $w$ ramach Europejskiego programu w zakresie migracji. COM (2016) 85 final. Bruksela (10.02.2016).

- $\quad$ KOMISJA EUROPEJSKA (2016b) Ósme sprawozdanie pótroczne z funkcjonowania strefy Schengen (1 maja - 10 grudnia 2015 r.). COM (2015) 675 final. Bruksela (24.02.2016).

- RADA (2017) Schengen: Rada zleca przedtużenie kontroli na granicach wewnętrznych, Available at: http://www.consilium.europa.eu/pl/press/pressreleases/2017/02/07-prolongation-border-controls.

- $\quad$ RISSE, T. (2009) "Social Constructivism and European Integration” In: WIENER, A. and T. DIEZ (eds.) European Integration Theory. $2^{\text {nd }}$ Edition. Oxford: Oxford University Press.

- $\quad$ ROOS, C. (2013) The EU and Immigration Policies: Cracks in the Walls of Fortress Europe?, Basingstoke: Palgrave Macmillan.

- $\quad$ TAYLOR, I. (2016) "EU migration crises: Greece threatened with Schengen area expulsion”. In: The Guardian. $25^{\text {th }}$ January.

- TROJANOWSKA-STRZEBOSZEWSKA, M. (2016) "Kryzys uchodźczy a przyszłość systemu Schengen”. In: WOJTASZCZYK, K. A. and SZYMAŃSKA, J. (ed.) Uchodźcy w Europie. Uwarunkowania, istota, nastęstwa. Warszawa: Oficyna Wydawnicza ASPRA-JR.

- $\quad$ van MUNSTER, R (2009) Securitizing Immigration. The Politics of Risk in the EU. Basingstoke: Palgrave Macmillan.

- W $\quad$ WEVE, O. (1996). “European Security Identities”. In: Journal of Common Market Studies. 34 (1). 
- WAlTERS, W. and HAAHR, J.H. (2005) Governing Europe: Discourse, Governmentality and European Integration. London: Routledge.

- WILLIAMS, M. C. (2003) "Word, Images, Enemies: Securitization and International Policies”. In: International Studies Quarterly. 47 (4). pp. 511-531.

- WILliaMS, P. D. (2012) “Badanie bezpieczeństwa. Wprowadzenie”. In: WILLIAMS, P.D. (ed.) Studia Bezpieczeństwa. Kraków: Wydawnictwo Uniwersytetu Jagiellońskiego. 